\title{
Introduction: Translating Koselleck
}

\author{
Stefan-Ludwig Hoffmann and Sean Franzel
}

Reinhart Koselleck's writings display a keen interest in individual linguistic expressions that are historically specific but also have a more general, formal reach, extending beyond the situations that gave rise to them. To take one example, he opens the essay "Structures of Repetition in Language and History" (chapter to in this volume) by quoting a witticism by the mid-nineteenth-century Viennese playwright and actor Johann Nepomuk Nestroy: “The strange thing with all these love stories is that they always revolve around the same thing, but how they start and end is so endlessly different that watching them never gets boring!"” As Koselleck notes, reading this in standard German (or English), rather than in the original dialect, one misses the unmistakable Viennese cadence of the original, even though the basic idea remains accessible. Koselleck goes on to translate Nestroy's remark, which originated in the world of nineteenth-century comic theater, into a more general thesis about the formal structure of historical events. Events are singular occurrences that surprise those who experience them. Yet this singularity unfolds historically in recurrent ways, recorded by the formulations of singular experiences by previous generations. Koselleck is attuned to historical specificity but also believes in a modest form of translatability, such that experiences captured in language can be applied to historical events that are potentially far afield from their original contexts. If singular events and experiences reoccur and are translated into language at different moments in time, wouldn't it be imperative for the historian to catalogue and theorize such reoccurring structures? To propose, not a philosophy of history that claims to know how all possible human stories start and end, but rather a set of abstract categories, serving as an analytical grid, that tell us what 
we might expect these stories to revolve around based on historical experience and evidence? A deliberately tentative theory that aims to break with the belief in "history," as it has evolved since the late eighteenth century with all of its ideological burden, and invites us instead to explore theoretically and in historiographical practice some of the conditions from which human conflicts, and hence possible histories, emerge?

\section{I}

Koselleck worked on his theory of history for most of his academic life, and there is surely something German about the idea that a discipline needs theoretical foundations. But while other postwar German theorists with similar ambitions for their own disciplines, such as Hans Blumenberg, Jürgen Habermas, or Niklas Luhmann, did produce large systematic works, Koselleck preferred the pointed essay as the vehicle for sketching out his theory; Montaigne's Essais was, after all, the third book (after the Bible and Jacob Burckhardt's Weltgeschichtliche Betrachtungen) that Koselleck would have wanted to have on a desert island. ${ }^{1}$ In stylistic terms this essay form is a careful and precise, yet open-ended, mode of carving out abstract categories that accounts for a set of theoretical issues from a variety of different, yet related, perspectives. Collected and for the most part translated here for the first time into English, these theoretical and historiographical essays were clearly the form he found congenial for illuminating structures of repetition from "the prescient past" (vorausgewußte Vergangenheit, one of many untranslatable phrases), a past that is known in advance, because it repeats previous experiences. ${ }^{2}$ Koselleck's prose is based upon a careful excavation of semantic layers contained in concepts, as well as upon the coinage of new and evocative concepts or metaphors. This explains why he is considered to be such a masterful stylist in German; but it is also the reason why he is notoriously difficult to translate for an anglophone readership.

It is perhaps not surprising that Koselleck returned time and again to the nineteenth century, the era in which the German philosophy and discipline of history rose to predominance. His first two books dealt with what he termed the Sattelzeit, the era between the mid-eighteenth-century Enlightenment and the 1848/49 revolutions, and authors from this period 
are frequently cited and evoked in his theoretical writings. One of the strengths of this work is that Koselleck mines these German intellectual traditions for his own arguments, making them thus available to readers today. But to describe the original language in which Koselleck thought and wrote, one has to situate his work in post-World War II Germany. Born in 1923, he experienced the Nazi period as an adolescent and young man, served in the German army, and was a Soviet prisoner of war in Central Asia until the fall of 1946; he then studied in postwar Heidelberg under Hans-Georg Gadamer, Karl Löwith, Viktor von Weizsäcker, Karl Jaspers, and others. Koselleck's intellectual concerns were formed by the experiences of World War II and its aftermath, and by the attempts to process these experiences in an academic landscape shaped by the Cold War division of Germany and the world, an era of global convulsions under the ever-present threat of nuclear annihilation.

Like Martin Heidegger and his students Gadamer and Löwith, Koselleck was steeped in the language of German idealist and existential philosophy, an idiom that has often proved challenging for English translators (including for us). Like his teachers, Koselleck tends to avoid latinate formulations, accounting, for example, for the temporal structure of historical events using German terms like vollziehen, sich ereignen, or sich zeitigen, rather than via cognates of "realize" or "manifest," and preferring Zusammenhang (constellation or connection) to Kontext. He likewise builds on the centrality of structures of anticipation or priorness in Heidegger's and Gadamer's hermeneutics, as expressed by the Vor- or "pre" in words like "preconception" (Vorgriff), "prejudice" (Vorurteil), or "pre-understanding" (Vor-Verstehen). At the heart of his theory of possible histories is an emphatic notion of structural "pregivens" (Vorgaben) that have formed experiences and events, and this term is not always easy to translate into English.

But Koselleck is also quick to point out how some concepts coined at earlier historical moments lose their applicability, addressing in particular the experience of being unable to continue to use certain Heideggerian concepts that evoked the conservative, militaristic intellectual milieu complicit with the rise of National Socialism in which Heidegger was situated. (In a late interview he called Heidegger's a "belt-buckle philosophy" [Koppelschlossphilosophie], ${ }^{3}$ evoking the military uniforms of 
the world wars.) Despite wanting to salvage certain formal features of Heidegger's analysis of the temporality of human experience, Koselleck rejects polemical esoteric concepts from Being and Time such as "being toward death [Sein zum Tode]," "calling [Geschick]," and "loyalty [Treue]" (see the essay "Historik and Hermeneutics" in this volume). In all of these essays, Koselleck pursues a strategy of de-escalating, de-polemicizing, and de-ideologizing theoretical language, rejecting a more partisan language in favor of a set of abstract structural and anthropological concepts. Koselleck seeks to translate Heideggerian ideas into a more neutral register, but also to historicize and discard certain overdetermined concepts that might obscure historical fact; for example, he argues that the German term Totschlagenkönnen- "ability to kill"-is better suited both historically and anthropologically to capture the human condition than Heidegger's "being toward death." Koselleck does pursue new conceptual coinages, seeking a theoretical register that might translate more generally and pluralistically into a range of historical experiences. Like Heidegger and other twentieth-century thinkers such as Michel Foucault or the early Frankfurt School, Koselleck sought to inaugurate a new conceptual language capable of coming to terms with modernity, ${ }^{4}$ but he does not do so in an ideological or insistent way.

2

If time defines history as a discipline, Koselleck posits, then a theory of historical time (or rather of a plurality of times) must be at the heart of the attempt to sketch out the conditions of possible histories. Koselleck's reflections on the challenge of giving expression to multiple temporalities shed light on his own theoretical language. In the introduction to his 2000 essay collection Zeitschichten, Koselleck speaks of the dependency of theorists of time upon spatial metaphors. He goes so far as to argue that "the metaphorical power of all images of time emerges initially from spatial visualizations [Anschauungen]," and that time can only be visualized through movement in specific units of space, as temporal concepts like progress (Fortschritt) or development (Entwicklung) indicate. "Every historical space constitutes itself through the time in which it can be measured, thereby becoming controllable politically or economically," 
Koselleck observes. In particular, spatial metaphors are needed to conceive of the simultaneity of the nonsimultaneous (die Gleichzeitigkeit des Ungleichzeitigen), and this is why Koselleck coins the concept of sediments or layers of time (Zeitschichten). ${ }^{5}$

Time is not linear and progressing from one period to another, as the modern concept of history suggests. ${ }^{6}$ Instead, there are multiple historical times present at the same moment, layer upon layer pressed together, some still volatile, others already hardened - this is what the metaphor of sedimented layers or strata of time attempts to capture. It is the tension between different and jarring layers of time that might erupt in historical events, as Koselleck demonstrated for the clash between the times of law, administration, and social change in Prussia before the revolution of I84849. In chapter 8 in this volume, "History, Law, and Justice" ("Geschichte, Recht, und Gerechtigkeit"), Koselleck engages with the history of legal concepts through the complex German concept of Recht, a notable challenge, for example, to translators of Hegel's Grundlinien der Philosophie des Rechts (Elements of the Philosophy of Right). In the German legal and philosophical tradition, Recht means law, legal system, and right, and is a cognate of the German word for justice (Gerechtigkeit), a term that is central to "Geschichte, Recht, und Gerechtigkeit." In this essay Koselleck explores the different temporalities of law and history, how law is by its very nature dependent on repetition and follows other rhythms than social change or political events, and how the law might generate social injustices or political conflicts because it remains in the continuum of its time. Characteristically, Koselleck then goes on to sketch out five modes, from ancient Greece onward, in which history has been set in relation to justice, ending with the totalizing notion of Friedrich Schiller's "Die Weltgeschichte ist das Weltgericht" (world history is the Last Judgment), which declares that history metes out justice in the here and now.

Other essays in this volume attempt further to differentiate Fernand Braudel's tripartite distinction among the longue durée of geographical and social structures, the moyenne durée of mid-term economic cycles, and événements, or short-term currents of political events. In contrast, "Structures of Repetition in Language and History" (chapter Io in this volume), one of Koselleck's last essays, is more interested in the interactions between different "times" and identifies five reoccurring structures, all belonging to 
what Braudel called the longue durée: the prehuman conditions of human experience (some of which, like the climate, may be altered by humanity); biological structures that humans share with animals; those humans don't share with animals (e.g., work and the law), structures of repetition contained in events; and, finally, structures of repetition contained in language. Only if we identify and analytically separate natural, biological, social or economic, political and linguistic structures of repetition can we empirically observe how their interactions condition possible histories.

In every repetition there is rupture and therefore the possibility of something new. Zeitschichten, Koselleck's portmanteau title for his essay collection, referring to "multiple temporal levels of differing duration and varied origin that are nonetheless simultaneously present and effective," merges "time" (Zeit) with "strata" (Schichten). (Cf., e.g., the German words Geschichte [history], which etymologically comes from Geschehen [occurence], and Gesteinsschichten [rock strata]. $)^{7}$ This term presents a spatial image of different coexisting layers, but also alludes to the process of these layers accruing or sedimenting at different speeds. It is in good part to access this process of accretion (and erosion) over time that we have chosen to translate Zeitschichten as "sediments" of time rather than the more geologically precise "strata." The metaphor of sediments captures the gathering, building up, and solidifying into layers of experiences and events, as well as the tensions and fault lines that arise between different kinds of sedimented formations (all metaphors that Koselleck uses throughout his writings). ${ }^{8}$ Indeed, in the essay "Forms and Traditions of Negative Memory" (chapter I5 in this volume), Koselleck describes the process of memory formation in terms of flow and solidification, here speaking of the events and experiences of the concentration camps: "They fill the memory of those affected by them, they form their memories, flow into their bodies like a mass of lava-immovable and inscribed."

Many of the central formal metahistorical concepts coined by Koselleck likewise seek to visualize complex temporal processes via spatial imagery. These include "sediments of experience" (Erfahrungsschichten) and "sluices of memory" (Erinnerungsschleusen), which describe how flows of experience, events, and memories are shaped, regulated, or redirected. Another good example is the conceptual pairing of "space of expectation" (Erwartungsraum) and "horizon of experience" (Erfahrungshorizont), 
which both establish ideas of a spatial outside or beyond in order to track different kinds of temporal unfolding, including the eclipse or overriding of past experiences by utopian expectations. ${ }^{9}$ Another such concept frequently used by Koselleck is "inventory" (Haushalt) — he speaks of inventories of language, of experience, of arguments, of emotions and more. The idea of a linguistic or experiential inventory likewise combines spatial and temporal imagery, with the inventory's contents being gathered and stored, organized, and reorganized over time. This is not an easy term to translate: "linguistic" or "experiential economy" might also work, tapping into older notions of the household (oikos) often mobilized by models of cultural memory, as might more literal spatial metaphors such as that of a commercial, domestic, or military storehouse, or arsenal. However, the important point here is that Koselleck uses this term to evoke a sense of temporal processes of repeated use, a sense of words and concepts that collect or accumulate over time. These various "inventories" are dynamic archives, for their contents are subject to being replaced by other words, concepts, or arguments, depending on historical shifts or ruptures, although they are more often characterized by stability and constancy.

Another place where Koselleck addresses the sedimentation of experiences in language is in his frequent citation of pithy, almost platitudinous sayings or maxims. In his important essay in Futures Past on the topos of history as the teacher of life (historia magistra vitae), first published in a Festschrift for Löwith, Koselleck details the dissolution of the rhetoricaltopological model of history, which dominated up to the eighteenth century and which posited that history teaches a certain set of moral lessons that recur over time. ${ }^{10}$ This earlier model was superseded by the modern concept of history as the unfolding of the new and the unique that could not be captured by the inventory of tropes catalogued by ancient, medieval, and early modern authors frequently evoked by Koselleck.

Seen in this light, it might appear peculiar that Koselleck gravitated toward certain almost axiomatic sayings that grasp structures of repetition in history. These include quotations from Goethe, who pursued a similar theory of history, something Koselleck realized only late in life ("the same event sounds different in the evening than it did in the morning"); the nineteenth-century author and illustrator of cautionary tales Wilhelm Busch: "First, it comes differently, second, not as you think" 
(Erstens kommt es anders, zweitens als man denkt); or more universal bits of folk wisdom such as "Time hurries and time heals" (Die Zeit eilt und die Zeit heilt) and "Sticks and stones may break my bones ..." Furthermore, Koselleck himself often translated his abstract historical theory into pithy new formulations: "One conflict comes to an end only when a new one begins," for example, in the interview with Carsten Dutt at the end of this volume (chapter I6).

At first glance, Koselleck's predilection for succinct formulas or folksy sayings might seem old-fashioned, anachronistic, or untimely (he defends untimeliness in his essay on "Goethe's Untimely History," chapter 5 in this volume), for the nineteenth- and twentieth-century German Bildungsbürger (educated bourgeois) was only too inclined to cite Goethe or Busch as moral authorities. But Koselleck is largely interested in adages that deal with the temporal structure of historical events and their experiences, as those cited above indicate. These sayings and maxims-often hard to translate, given their highly idiomatic nature-largely boil down to questions of temporal sequence or change through time, change in perception, change in memory, and so on, and, for Koselleck, they signal the consolidation of human experiences in recurring structures. By attending to certain expressions that are tied to specific historical experiences, but that have broader formal application, he shows how structures of persistence and repetition can manifest themselves. Koselleck's provocation is to ask us to consider how, even in modernity, structures of repetition and constancy persist and relate to one another, and these sayings are sites where these structures can be glimpsed, where repeated and repeatable experiences solidify into knowledge that extends beyond the context of these sayings' initial utterance. This is neither an attempt to reground history writing in certain immutable topoi nor, concomitantly, to detemporalize historical experience and language in an era when all experience and language has been temporalized. Koselleck merely reminds us that the experience of the new is always based on possibilities of repetition, and that we need to know what repeats in order to understand what is new. 
Arguably, there has been an uptick of interest in Koselleck since his untimely death in 2006, especially since the publication of Niklas Olsen's excellent intellectual biography, History in the Plural (2012). ${ }^{11}$ Whenever scholars deal with issues of temporality, with present pasts or past futures, Koselleck's writings are invoked. But the recent surge in interest in Koselleck's work makes it even more conspicuous that his name was more or less absent from late twentieth-century anglophone critical theory or in the excruciating methodological debates about linguistic and cultural turns. If there was one historian who had thought long and hard about language and history and, in response to Gadamer, about why history is not a subdiscipline of hermeneutics, it was Koselleck. Yet in the avalanche of manifestos after the arrival of French poststructuralism on American shores, debating whether "all the world is a text," Koselleck is rarely mentioned. This is all the more striking because the debate revolved precisely around questions (such as the evidence of experience or the extralinguistic preconditions of linguistic change) that were at the center, not only of Koselleck's writings on conceptual history, but, more generally, of his theory of the conditions of possible histories, his Historik.

Of course, many of Koselleck's theoretical writings were not translated into English. Still, this is only part of the answer and does not explain the puzzlement and skepticism that some of his translated works provoked in the United States - in marked contrast to France, where Koselleck has been recognized as the most inspiring German theorist of history of the late twentieth century, first by Paul Ricour in his Temps et récit (198385), especially volume 3, Le temps raconté, and, more recently, by François Hartog in his explorations of contemporary experiences of time, what he calls "presentism."12

The late 1980 s and early I990s seemed like the perfect moment for a more sustained reception of Koselleck's work in the anglophone world. After a delay of thirty years, his first book, Kritik und Krise, was finally published in English translation (1988). ${ }^{13}$ Three years earlier, his important collection of essays Vergangene Zukunft (1979) had appeared in English translation in MIT Press's series Studies in Contemporary History, edited by Thomas McCarthy. Futures Past received prominent reviews by David Carr and Hayden White, the latter calling him "one 
of Germany's most distinguished philosophers of history." ${ }^{14}$ In I986, Koselleck had been a visiting professor at the New School for Social Research in New York, and in the fall of 1988 , he was invited to be a visiting professor in the History Department at the University of Chicago. Earlier that year, he had retired from his position at the University of Bielefeld, and his appointment at Chicago was meant to be renewable. The French historian François Furet, with whom Koselleck had co-authored a book in the late I960s, and had remained friends, had already been at Chicago on and off since 1980, more permanently since 1985. After 1990, Furet shifted completely to the Committee on Social Thought, an arrangement that Koselleck would probably have also wanted for himself. ${ }^{15}$ But Koselleck's impact at Chicago was much more limited than Furet's. After three fall quarters with a total of six courses, Koselleck's appointment was not renewed. He did accept invitations to teach again for the fall quarter at the New School (1991) and at Columbia (1992), but this was the last time that Koselleck taught in the United States.

Irrespective of why Koselleck's appointment at Chicago was not renewed, his work evidently did not translate as well into English as that of Habermas, for example, whose Structural Transformation of the Public Sphere appeared in English translation in the same series in 1989. Of course, Critique and Crisis was also an important reference point for Habermas's own take on some of the same questions. As Anthony La Vopa asserted in a 1992 review essay, Critique and Crisis and Transformation of the Public Sphere both "reflect the political preoccupations of the I950s, though from opposite ends of the ideological spectrum."16 Both studies take Kantian philosophy as their starting points—and both were influenced by Schmitt. Whereas Koselleck aimed for a conceptual genealogy of the political function of Kant's critiques (the original working title of his 1954 Heidelberg dissertation had been Dialektik der Aufklärung), ${ }^{17}$ Habermas wrote an affirmative account of Kant's idea of publicity, which, he argued, had been corrupted in the nineteenth century by the rise of capitalism and mass culture. However, it was Habermas's Transformation of the Public Sphere that became one of the most influential books by any German theorist in anglophone academe in the I990s. ${ }^{18}$ The question, of course, is why? 
One reason was certainly the problem of translation. Part of why Critique and Crisis had become an instant classic in 1960s West Germany was Koselleck's suggestive writing style, his use of the different semantic layers of social and political concepts to craft historical arguments. Critique and Crisis was itself an early exercise in Begriffsgeschichte, conceptual history, a feature of the book that got lost in the literal translation of the English edition (for which, quite unusually, no translator claimed responsibility). The Cambridge historian T. C. W. Blanning articulated what was probably a common reservation for anglophone historians when he complained in his 1989 review about "the gargantuan German footnotes" in Critique and Crisis. These footnotes contained many succinct conceptual histories, however. According to Blanning, Koselleck's prose was hard to understand, inasmuch as it "soars into a metaphysical stratosphere and has no discernible relation to what was happening on the ground." ${ }^{19}$ Blanning compared Critique and Crisis unfavorably to Hans-Ulrich Wehler's The German Empire, which was surely no less Germanic in its prose, excessive footnotes, and polemical style. Of course, Wehler was also Koselleck's colleague and intimate enemy at Bielefeld, with close ties to anglophone academe. Never shy to pick a "lively situation of contestation," Wehler had claimed ten years earlier, in Haberman's programmatic edited volume Stichworte zur "Geistigen Situation der Zeit», that Koselleck's conceptual history was a "historicist dead end" at best. ${ }^{20}$

The distance between Koselleck and Wehler (or Habermas) also had to do with different wartime experiences. Whereas Wehler, Habermas, and the "45ers" generation of postwar German intellectuals were too young to have been drafted into the Wehrmacht and embraced American reeducation after the war as liberation, Koselleck's experiences of the catastrophic absurdity of mass death during the war and in its aftermath were deeply formative for his own understanding as being defeated. As he noted in his introduction to Critique and Crisis, written only a few years after his return from the war and the Gulag, "[ ... ] man as a historic[al] creature is always responsible, for what he willed as well as for what he did not will, and more often, perhaps, for the latter than for the former." ${ }^{21}$ A son of a liberal Weimar German professor with some distance from the Nazi regime, Koselleck regarded himself as intellectually neither a former Nazi nor a product of (American or Soviet) reeducation. He was thus happy 
to talk to anyone he found inspiring in postwar Heidelberg, including Heidegger and Schmitt, both of whom had lost their professorships after the war on grounds of complicity with the Nazi regime.

In his acceptance speech on receiving the Munich Historische Kolleg's prize in 1989, for example, Koselleck explicitly stated that his education at Heidelberg would have been unthinkable without the questions raised by Heidegger and Schmitt, even though he did not necessarily agree with their answers. ${ }^{22}$ However, Critique and Crisis's indebtedness to Schmitt, especially to his 1938 The Leviathan in the State Theory of Thomas Hobbes, proved to be decisive for its reception, and not only in West Germany. Habermas himself had insinuated in a 1960 review that anyone who wanted to know what Schmitt was then thinking should read Critique and Crisis. ${ }^{23}$

In the same year, the Harvard émigré political scientist Carl J. Friedrich reviewed Critique and Crisis for the American Political Science Review. Together with his young colleague Zbigniew Brezezinski, Friedrich had written Totalitarian Dictatorship and Autocracy, one of the most influential books of Cold War American social sciences, which came out in 1956, the year of the Hungarian revolt against Soviet control. Given his staunch anti-communism and critical views of the Enlightenment and French Revolution, one might have expected Friedrich to be sympathetic to Critique and Crisis's anti-totalitarian bent. Instead, he focused entirely on the influence of Carl Schmitt on Critique and Crisis. Schmitt, Friedrich wrote, "is singled out for acknowledgment and [his] works are copiously cited. The 'decisionism' of this author leads Dr. Koselleck to think of absolutism primarily in terms of 'sovereign decisions'-only one of the aspects of this complex system of government. The discussion abounds in certain words fashionable in these circles, such as 'sprengen' [to explode], 'Raum' [space] and its various derivates, 'verorten' [emplace] and so on.” Some of Friedrich's other criticisms of Critique and Crisis may have had something to do with his intimate knowledge of Heidelberg, and especially his close ties to his former mentor Alfred Weber, who was also one of Koselleck's teachers after the war. In any case, Friedrich set the tone for the later reception of Critique and Crisis: "Inspired by antiliberal and antibürgerlich sentiments, it is a brilliant exposition of a theme that seems rather dubious, where it deviates from familiar paths." ${ }^{24}$ 
In 2004, Koselleck himself conceded the "slightly mannered severity of his argumentation" in Critique and Crisis, and he never made a secret of the influence of Schmitt's conceptual rigor (but not his politics) on his writings. In fact, Koselleck developed his own intellectual program of a theory of history in his early correspondence with Schmitt. ${ }^{25}$ Karl Löwith's Meaning in History (1949), which Koselleck helped to translate into German as Weltgeschichte und Heilsgeschehen. Zur Kritik der Geschichtsphilosophie (1953) while writing his dissertation and, of course, Hannah Arendt's Origins of Totalitarianism (195I), which appeared in an expanded German version in 1955 (now after Stalin's death including a chapter on "Ideology and Terror"), were just as important for his work. Löwith's critique of the philosophy of history as a secularized form of Christian eschatology was one of the starting points for Critique and Crisis. And Arendt's work in particular guided Koselleck's argumentation for the published version of his dissertation. However, these and other influences were occluded by Koselleck's affiliation with Schmitt. As Koselleck wrote with indirect reference to Habermas's 1960 review in 2004, two years before he died:

Thus whoever expressed thanks to Carl Schmitt was labeled a mouthpiece of Carl Schmitt. Whoever cited eighteenth-century conspiracy theories became a conspiracy theorist. Whoever criticized a politically or morally inspired dualism became a dualist. The opposite, however, is the case: the mutual dependency of politics and morality was in fact the normative implication of my argumentation. My critique of utopia was based on the disclosure of the polemical juxtapositions of the two entities lurking behind mauvaise foi or hypocrisy: the utopian designs for the future, the implementation of which would make princes disappear as tyrants. And for this reason there would no longer be any tyranny, wars as well would be permanently ended, and ultimately peace-loving citizens would make the state disappear [ . . ]: All of these-as we now know, dangerous and bloody-illusions arose directly from the inadequacy of thinking or implementing morality without politics or politics without morality. ${ }^{26}$

It was Koselleck's intention to unveil the agonistic utopian philosophies of history, which he considered to dominate the Cold War confrontation of the I950s between communism and liberal democracy. Like Jacob Talmon in his Origins of Totalitarian Democracy, written at the same time in 


\section{Introduction}

Jerusalem (part I published in 1952 and part 2 in 1960), Koselleck looked to the Enlightenment for the genealogies of twentieth-century utopian ideologies. Koselleck's primary political concern was the ideological potential for global self-annihilation in the Nuclear Age rather than some Schmittian justification for Third Reich expansionism or postwar German selfpity. He was, like Talmon or Arendt, politically a Cold War liberal, "an enlightener of the enlightenment," as Ivan Nagel put it in his 2006 obituary, borrowing a phrase that Koselleck had used to describe himself. ${ }^{27}$

If there is a political lesson contained in Koselleck's theory of history, it is the necessity of consensus and compromise. As he argues in "Concepts of the Enemy" (chapter I2 in this volume)—a postscript to his famous essay on "The Historical-Political Semantics of Asymmetric Counterconcepts" - all human experiences are organized by a here and there, an inside and outside, and it as essential for a political unit of action to solidify these boundaries as it is to transcend them. "Without contacts and contrasts, without conflict and compromises, without the building of this or that form of consensus, no group could exist or survive, at least not in our complex society." In the 1980 os Koselleck co-edited a volume on the nuclear arms race that was academic in tone but no less political as an intervention. Characteristically, his introduction urged both sides of the debate in the West-the peace movement as well as those advocating nuclear deterrence against the Soviet Union-to translate their shared apocalyptic visions of nuclear annihilation into rational political arguments. ${ }^{28}$

\section{4}

It was not merely the affiliation with Schmitt or Heidegger that made the reception of Koselleck's work difficult in the anglophone world. Koselleck's reputation in German intellectual life, especially among German historians in the 1960s and I970s, was built on much more than Critique and Crisis. In many ways, he became a historian (and received an appointment, a Lehrstuhl, in history) as a result of his Heidelberg Habilitation Preußen zwischen Reform und Revolution (1967), which has not been translated into English, as well as for his ambitious lexicon project Geschichtliche Grundbegriffe (Basic Concepts in History; 8 vols., 1972-92). 
Becoming the main editor of Geschichtliche Grundbegriffe and participating in the Poetik und Hermeneutik group propelled Koselleck into the center of German intellectual life in the I960s and I970s. Some of the essays in Vergangene Zukunft (1979) were also part and parcel of Koselleck's studies of the history of particular concepts like crisis, critique, revolution, history, and modernity, or the modern era (Neuzeit), which had informed his empirical work as a historian. ${ }^{29}$

But the Geschichtliche Grundbegriffe lexicon also made Koselleck's theoretical reflections seem primarily like explorations of conceptual history as a method. Conceptual history became almost synonymous with Koselleck's name, and Geschichtliche Grundbegriffe was henceforth a straitjacket, not only for his writings, but perhaps also for his reputation abroad. ${ }^{30}$ In an interview with the Italian historian Edoardo Tortarolo in 1989 , Koselleck himself articulated the intellectual constrains imposed on him by what he called his penal labor (Strafarbeit) on Geschichtliche Grundbegriffe. "Because I am really not interested in this method anymore. If you've invested a quarter of century in something, it's just no fun anymore to work with this method, it has become boring for me." ${ }^{31}$ Koselleck thought of conceptual history as only a methodological and empirical starting point (hence the lexicon format) for historical and theoretical explorations of any kind. Ironically, Koselleck came to be known as a conceptual historian at a time when his interests had shifted toward strikingly new and original theoretical questions, which all came to revolve around the question of the conditions of possible histories. Koselleck's unique theoretical approach allowed him to write about dreams and prognoses, death and iconography, war experiences and memory, and always in new variations on time: the times of law, history, space, humanity and what is now called "deep time," that is the time before the anthropocene.

Koselleck was such a unique and original historian because he was at the same time a theorist. This also explains the failed conversation with Quentin Skinner and John Pocock, who shared an interest in political languages with Koselleck. In retrospect, one has to admire Melvin Richter's advocacy in America since the mid-I980s of conceptual history as a historical method (ultimately, without lasting success) in his pointing out its similarities to the approach of Skinner, Pocock, and the Cambridge School of Intellectual History. There were probably more differences than 
similarities between the two approaches, however, and the main differences are less methodological (which was at the center of the debate) and have more to do with the theoretical implications of Koselleck's work, something he might have been aware of. ${ }^{32}$ In December 1992, Richter was finally able to put together a symposium on Geschichtliche Grundbegriffe at the German Historical Institute in Washington, DC, marking the completion of the lexicon that same year, which brought Koselleck and Pocock into direct dialogue for the first time.

Language, ironically enough, turned out to be one of the main barriers for this conversation. Pocock (like Skinner) lacked any first-hand knowledge of Koselleck's writings (with which he was familiar only through Richter's summaries). Still, his comments were more cautiously critical than Skinner's earlier assertion that the notion of a diachronic history of individual concepts is fundamentally flawed. As Koselleck later explained to Richter, he had difficulties answering Pocock on the spot, because he had been unable to understand Pocock's English accent, with its unique blend of Cambridge and New Zealand. But even years later, when Koselleck did find the time to write a more formal response to Pocock, his tone was uncharacteristically brusque. "As my previous comments indicate, I dealt with the issues he raises already long ago," he declared. ${ }^{33}$ Thus, the anglophone history of political languages and German conceptual history continued to exist in parallel after the symposium, Richter's advocacy of combining the two notwithstanding. With the curious exception of anglophone academia, Begriffsgeschichte has gone global in the past ten years, and it is particularly strong today in Scandinavia, eastern Europe, and the Spanish-speaking world. The theoretical underpinnings of Koselleck's Begriffsgeschichte, including his critique of the ideological use and abuse of modern concepts such as "history" have more in common with Foucault's archeology than with Pocock's and Skinner's much more contextual interests. ${ }^{34}$

Up until very recently, however, Koselleck was perceived either as a conservative historian of the eighteenth and early nineteenth century à la Furet or, more generally, as a Begriffshistoriker, that is, an intellectual historian/historian of concepts à la Pocock and Skinner or a meta-historian à la White (if not as a "philosopher of history," something Koselleck always abhorred). Of course, Koselleck repeatedly insisted that all these 
different interests belonged together. Yet only the three collections of essays, Zeitschichten, Begriffsgeschichten, and Vom Sinn und Unsinn der Geschichte, published in the years immediately before and after his death in 2006, and from which all the writings in this volume are taken, make apparent how these different interests are laced together in his theory of possible histories. ${ }^{35}$ Instead of borrowing theoretical concepts from other disciplines, Koselleck believed that historians should develop their own epistemology, with being in time (following Heidegger's lead) ${ }^{36}$ as its defining episteme. From Koselleck's perspective, his studies in conceptual history were only a kind of propaedeutic for a fundamental theory of history, the first systematic outline of an epistemology of history since Johann Gustav Droysen's Historik (I858). Consequently, Koselleck speaks emphatically of history as a science (Wissenschaft) in the essays in this volume, an ambition that does not translate well into the anglophone "discipline" of history.

A case in point is the ninth essay in this volume, his inaugural public lecture, as Lurcy Visiting Professor at Chicago, on "Language and History," perhaps the most cogent summary of his theory of history that Koselleck delivered for an English-speaking audience. In his lecture, Koselleck insisted on the fundamental difference between language and history. At a time when theoretically infatuated anglophone historians debated whether "all the world is a text," the conceptual historian Koselleck delivered an untimely reminder of the prelinguistic conditions of all possible histories. It is precisely his interest in language that explains why Koselleck is so careful not to confuse res factae (historical reality) and res fictae (fiction), res gestae (things done or Geschichte) and historia rerum gestarum (things written about it or Historie). This was his argument against Gadamer and the hermeneutic tradition, and it was also what sets him apart from intellectual compatriots like Paul Ricœur or Hayden White. For Koselleck, these prelinguistic conditions included the tensions between "earlier" and "later," "inner" and "outer," and "above" and "below"- abstract sets of universal contraries that condition all particular histories, and that he had sketched out in a slightly different form three years earlier in "Historik and Hermeneutics" (chapter 4 in this volume) and, more than thirty years earlier, as a graduate student still in Heidelberg. ${ }^{37}$ His second set of arguments concerned the 
temporal differences between language and events. History is always more than language can grasp, and concepts contain more or less than what occurs in the actual course of events. "Language adjudicates above all as to the possibility of an actual history," Koselleck asserts in "Linguistic Change and the History of Events" (our chapter 9), "As a storehouse of experiences, language bundles together the conditions of possible events." We cannot know how a particular event-whether a revolution, civil war, military defeat, or social and economic crisismight unfold, but we can access some knowledge of the possibilities that are contained within historical experience and captured by language.

For Koselleck, history is above all a science of experience, an Erfahrungswissenschaft, and experiences also determine the language of the historian. Here, Koselleck applies his abstract, systematic categories of the prelinguistic conditions of all possible histories to historiography itself. The historian's perspective is conditioned by temporality, the question of whether he or she is a contemporary of the events reported on, or was born later. Next it is important whether he or she is "higher" or "lower"-for example, is among the winners or the losers. And, finally, it is decisive for the historian's perspective whether he or she is on the "inside" or the "outside," that is, part of the polity being described or looking on from the outside. From here, Koselleck moves on to discern three dominant modes of historiographical writing that are likewise structured by temporality and capture past experiences linguistically: writing down (Aufschreiben) at the moment when events occur; copying (Abschreiben), that is, transmitting the meaning once attached to particular events; and rewriting (Umschreiben) under the pressure of new experiences that call for new explanations of familiar events. ${ }^{38}$

\section{5}

And yet there are certain experiences that elude capture by language. It seems clear that Koselleck's theoretical interests are refracted through his experience of World War II, and that this lies behind his insistence on the difference between primary and secondary experiences, those that can be put into words and perhaps be transmitted to others, and those that "flow into their bodies like a mass of lava-immovable 
and inscribed." Koselleck shares with Arendt an existential understanding of the ruptures of the I940s, which lead both of them to radically critique the modern concept of history. ${ }^{39}$ Arendt and Koselleck believed that the catastrophes of the twentieth century were caused by ideologies that claimed to execute the laws of history. This theme of the political hypocrisy of the Enlightenment's philosophy of history was already the argument of Koselleck's dissertation, resurfaces in different essays throughout the 1960s, 1970s, and I980s (e.g., in "History, Law, and Justice," where Koselleck speaks about the absurdity of history as exemplified by Nazi evil), and comes to the fore again in his late essayistic work. "On the Meaning and Absurdity of History" and "Forms and Traditions of Negative Memory" (chapters II and Is in this volume) are two examples of his polemics against the political evocation of history, as if the meanings of historical events could be contained and controlled. It is the senseless absurdity of mass killing, its "abysmalness" that makes it difficult for the survivors to transform their individual primary experiences into a "history" or "collective memory." Of course, historians can retroactively write an account of the events of World War II and the Holocaust and provide explanations for the course of events. But histories in the moment of their unfolding (in actu, as Koselleck would say) are not rational and are only carried out in the perspectively refracted perceptions of the participants, like in the novels of William Faulkner or Leo Tolstoy. "Ideas, formulated intentions, desires, generated linguistically as prelinguistically, taking and holding something to be true, all of these enter into the situation out of which events crystallize. What the different agents hold to be real about a history as it arises and is carried out in actu pluralistically constitutes the history to come. [ . . . ] As events ferment or occurrences are intertwined, as conflicts pile up and then break through, there is no common reality that can be perceived in the same way by the different participants involved" (chapter II).

Koselleck lost both of his brothers in World War II: the older died at the front a few weeks before the end of the war, the younger at home when his parents' house was hit by an Allied bomb. One of his aunts was gassed during the Nazi euthanasia campaign in 1940. He was conscripted into the army at seventeen and deployed to the Eastern front. In 1942, Koselleck's foot was crushed in an accident when his artillery regiment 
marched toward Stalingrad — the injury probably saved his life. Koselleck returned home and spent time in hospitals. At the front he had heard rumors about the mass killings of Jews at Babi Yar near Kiev. Visiting family in Weimar after his release from the hospital in February 1943, he also learned about Buchenwald. Eventually, Koselleck was redeployed to a Wehrmacht radar unit in Strasbourg. In the last months of the war, he was again sent to the Eastern front, which by then had reached German territory. His unit fought against the Red Army in Moravia. Once in Soviet captivity on May 9, I945, he had to march on foot to Auschwitz for two days, together with thousands of other German prisoners of war.

There he took part in the dismantling of the IG Farben chemical factories, which were sent by train to the Soviet Union for reassembly. After a few months, the German prisoners were put on eastbound trains themselves. A few weeks later, Koselleck arrived at Karaganda in Central Asia, an industrial coal-mining city built in the Kazakh steppe primarily by Stalin's convicts and deportees of the I930s and I940s, many of them Volga Germans and other Soviet ethnic minorities. Not all prisoners survived the transport, and most were initially not in a condition to work at all. The Karaganda region itself was a dystopian place with harsh cold winters and brutal summer heat, populated by settlements of deportees and Gulag camps, including separate camps for German and Japanese prisoners of war. ${ }^{40}$ At his camp in Spassk, south of Karaganda, Koselleck encountered hunger and diseases (the main cause of death everywhere in the Soviet forced labor penal system), but also Marxist-Leninist (or rather Stalinist) ideologies of reeducation and redemption. In 1947, now a student in Heidelberg, Koselleck attended a reeducation seminar at Göhrde castle. One of the teachers was the young Marxist historian Eric J. Hobsbawm, deployed as a British reeducation officer. Hobsbawm recalls in his memoirs the lasting impression of Koselleck's report about Karaganda, how difficult the conditions were for the German prisoners and for the Soviet guards alike, both displaced in the Kazakh steppe, but how the latter were much better able to cope (at least in Koselleck's perception). ${ }^{41}$

Koselleck survived the camp thanks to another inmate, who recognized the symptoms of a fatal illness, and with the help of a German military doctor who had been an assistant to his uncle, a famous pathologist at Leipzig University. After fifteen months at Spassk and another surgery, 
this doctor declared Koselleck unable to work but strong enough for transport back home. Arriving at the border between Poland and the Soviet zone of occupation in East Germany in September 1946, Koselleck was given a copy of the Communist Manifesto. Later in the French zone, where his family lived, he was briefly arrested by the police, who took him for a vagrant. American Baptists replaced his ragtag Soviet prisoner clothes and provided him a copy of the Bible. Upon arrival at home his father politely asked him for his name-he didn't recognize his son.

Two-thirds of Koselleck's class in school didn't return home. He survived by chance but also by social privilege. In "Sluices of Memory and Sediments of Experience" (chapter 13 in this volume), he painstakingly analyzes how war experiences are shaped differently according to social and cultural categories. Dying in a war is unpredictable, but who survives is not necessarily so. Koselleck's fierce critique of moral hypocrisy was itself deeply moralistic, as is often the case. This holds true not only for Critique and Crisis. Most essays in this collection, written between 1976 and 2006 as explorations of his theory of history, return at central moments to the questions of Nazism, war, and the Holocaust.

Unsurprisingly, Koselleck's writings become most polemical when concerned with questions of memory and mourning. "Forms and Traditions of Negative Memory" is a case in point. After the end of the Cold War and the division of Germany, Koselleck participated in the debate about the Neue Wache ("New Guardhouse") war memorial and the Holocaust Memorial in Berlin, the only time when he felt compelled to participate directly in German political debates. In his intervention against the planned Neue Wache Memorial (a critique ignored at the time by German Chancellor Helmut Kohl), Koselleck comes back to an argument that guided his research into the iconography of nineteenth- and twentieth-century European war memorials. In modernity, increasingly abstract monuments for fallen soldiers (and, after the two world wars, also for dead civilians) signify a democratization of death. The commemoration of fallen soldiers, as individuals or in groups, replaced war memorials with great personages like monarchs or generals, and the dead came to represent the nation. But this democratization relies on sharp demarcations between "us" and "them," that is, those who belong to a nation and those who are excluded. War memorials thereby become sites of identity 
formation for the survivors. The dead are not treated equally but are grouped and categorized by the political agendas of different political communities of action (Handlungsgemeinschaften). Koselleck was appalled by Kohl's idea of transforming a small and intimate sculpture by Käthe Kollwitz, a pietà of a mother holding her dead son in her arms, into reunified Germany's main war memorial. He passionately pointed out the different forms of exclusion entailed by the visual language of the Kollwitz sculpture (created to commemorate her son who died in World War I). How, he demanded, could a Christian pietà alluding to the Virgin Mary holding the dead body of Jesus commemorate the murdered European Jews?

Koselleck also directed his chagrin against the dedication "To the victims of war and dictatorship" (Den Opfern von Krieg und Gewaltherrschaft), which transformed World War II and the Holocaust into a history without perpetrators, only victims. How could a World War II German national memorial portray Germans as victims like any other people? Instead, he proposed emphasizing mourning the dead without social, political, or national-ethnic distinctions, but differentiating how they died: "To the dead — to the fallen, the murdered, the gassed, the perished, the lost" (Den Toten-gefallen, ermordet, vergast, umgekommen, vermisst), a dedication that is equally problematic, of course, since it would also have lumped Wehrmacht soldiers and Holocaust victims together. Similarly, he argued only a few years later in 1998 against the Berlin Holocaust Memorial being the central site of the commemoration of German genocidal policies, since its dedication ("To the Murdered Jews of Europe") did not include all the other groups and peoples murdered by the Nazi regime, for example, the Sinti and Roma (who received their own memorial in the proximity of the Holocaust Memorial only in 2012) and the three and a half million Soviet prisoners of war who died in German captivity but are not commemorated at all by a central memorial, either in Germany or in Russia. Instead of a central state memorial that remembers all those murdered by Nazi Germany, the commemorative landscape in Berlin is now splintered into various monuments of various shapes and sizes for different (but not all) victim groups, based on the categories of the SS, exactly as Koselleck had predicted in the I990s. 
"Mourning is not divisible," as Koselleck sums up his position in "Forms and Traditions of Negative Memory." Germans should not only remember the victims but also the perpetrators of World War II, who murdered others and sacrificed their own lives (the Opfertod) for an immoral and abysmal cause, a cause that completely transformed the meanings of "victim" (Opfer) in German from active sacrifice to passive endurance (Leiden, Erleiden), terms Koselleck employs in these essays to avoid the charged concept of victimhood. Koselleck's use of the idiosyncrasies of his own biographical ruptures as a prism for his theoretical essays opens up his experiences to critical reflection and, conversely, makes his theory historically concrete and legible. For Koselleck, the mid-twentieth-century cataclysms of modernity, which he experienced both as a soldier, that is, a "perpetrator" (in the Wehrmacht) and as a camp prisoner, that is, an "endurer" (in the Gulag) completely dissolved any meanings attached to "history." History itself is without meaning, only its analysis can be rational and meaningful-hence the need for a theory of history. This is the leitmotif of Koselleck's Historik. 
This page intentionally left blank 